\title{
MODEL PROBIT SPASIAL PADA FAKTOR-FAKTOR YANG MEMPENGARUHI KLASIFIKASI IPM DI PULAU JAWA
}

\author{
Feni Ira Puspita', Vita Ratnasari2, Purhadi ${ }^{3}$ \\ Jurusan Statistika, FMIPA, Institut Teknologi Sepuluh Nopember \\ e-mail: 1irapuspitafeni@gmail.com,2vita_ratna@statistika.its.ac.id,3Purhadi@gmail
}

\begin{abstract}
ABSTRAK
Indeks Pembagunan Manusia (IPM) merupakan suatu indeks komposit yang mencakup tiga dimensi pokok pembangunan manusia yang dinilai mencerminkan status kemampuan dasar penduduk yaitu kesehatan, pencapaian pendidikan, dan daya beli masyarakat. Data IPM dikategorikan/ diklasifikasikan menjadi empat, yaitu rendah, menengah ke bawah, menengah ke atas, dan tinggi. Oleh karena itu, penentuan data IPM dapat dilakukan dengan pendekatan regresi probit. Secara data didapati bahwa terdapat kemiripan nilai IPM antar wilayah yang berdekatan secara geografis yang mengakibatkan klasifikasi IPM wilayah yang berdekatan tersebut sama. Hal ini diduga karena adanya depen-densi/keterkaitan hubungan antar wilayah. Fenomena ini diduga karena adanya dependensi spasial yang dapat dijabarkan melalui metode spasial. Dari penjabaran di atas, maka data IPM dalam penelitian ini didasarkan pada metode regresi probit spasial yang akan dibandingkan dengan metode probit. Penelitian ini bertujuan mengkaji penaksir parameter dan pengujian penaksir parameter yang diaplikasikan pada data klasifikasi IPM di Pulau Jawa. MCMC digunakan sebagai metode pada pengkajian penaksir parameter.Sedangkan pengkajian pengujian parameter yang digunakan ialah 25\% sampai $75 \%$ dari estimasi parameter.
\end{abstract}

Kata kunci: IPM, MCMC, Probit,Probit Spasial

\section{ABSTRACT}

Human pembagunan Index (HDI) is a composite index that includes three basic dimensions of human development is considered to reflect the status of the population's basic abilities of health, educational attainment, and purchasing power. Data IPM classified into four, namely low, lower middle, upper middle, and high. Therefore, determining the HDI can be done with the data probit regression approach. In the data found that there were similarities between the HDI value of geographically adjacent regions which resulted in the classification of the adjacent HDI same region. This is presumably due to the inter-regional dependency. This phenomenon is suspected because of the spatial dependencies can be described through spatial methods. From the explanation above, the HDI of data in this study are based on the spatial probit regression method are compared with the probit method. This study aims to assess the predictors for estimating parameters and testing parameters were applied to the data classification IPM in Java. MCMC is used as a method of estimating the parameters in the assessment. While the assessment test parameters used are $25 \%$ to $75 \%$ of the estimated parameters.

Key words: IPM, MCMC, Probit, Spatial Probit

\section{PENDAHULUAN}

Hakekat pembangunan dalam suatu wilayah adalah proses multidimensional yang mencakup perubahan yang mendasar meliputi struktur-struktur sosial, sikap-sikap masyarakat dan institusi-institusi nasional dengan tetap mengejar akselerasi pertumbuhan ekonomi, penanganan ketimpangan pendapatan serta pengentasan kemiskinan. Keberhasilan pembangunan khususnya pembangunan manusia menempatkan manusia sebagai tujuan akhir dari pembangunan bukan alat dari pembangunan. Keberhasilan pembangunan manusia dapat dilihat dari seberapa besar permasalahan men- dasar di masyarakat dapat teratasi. Permasalahan-permasalahan tersebut meliputi kemiskinan, pengangguran, gizi buruk, dan buta huruf (BPS, 2009).

Salah satu alat ukur yang dianggap dapat merefleksikan status pembangunan manusia adalah Indeks Pembangunan Manusia (IPM) atau Human Development Index (HDI). UNDP sejak tahun 1990 menggunakan IPM untuk mengukur perkembangan pembangunan manusia. IPM merupakan suatu indeks komposit yang mencakup tiga dimensi pokok pembangunan manusia yang dinilai mencerminkan status kemampuan dasar penduduk yaitu kesehatan, pencapaian 
pendidikan, dan daya beli masyarakat. Di samping mengukur kinerja pembangunan ma-nusia, perlu disadari bahwa IPM yang sebagai indeks komposit hanya dapat memperlihatkan perbandingan antar daerah provinsi atau kabupaten/kotamadya dan perkembangan antar waktu. Oleh karena itu, diperlukan juga untuk melihat komponenkomponen yang membentuk IPM tersebut sehingga diketahui pencapaian dari masingmasing komponennya.

Menurut laporan BPS (2011), kondisi pembangunan manusia Indonesia mengalami kemajuan yang pesat. Selama tahun tahun 19962010, angka IPM telah meningkat 4,57point menjadi 72,27. Hal ini juga konsisten dengan peningkatan komponen pembentuknya, kecuali komponen daya beli yang sempat merosot akibat guncangan krisis ekonomi 1998.

Penelitian mengenai faktor-faktor yang mempengaruhi nilai IPM pernah dilakukan oleh Yurviany (2007) dan Salam (2008) yang masingmasing menggunakan metode analisis regresi logistik dan pemodelan regresi logistik ordinal sedangkan Diana (2009)menggunakan regresi multivariat. Sementara Arianti (2009) dengan menggunakan cluster analysis, dan Faidah (2010) dalam penelitiannya menggunakan regresi probit ordinal dan mengklasifikasikan kabupaten/kota berdasarkan model yang telah diperoleh.

Data IPM diklasifikasikan menjadi empat, yaitu rendah, menengah ke bawah, menengah ke atas, dan tinggi (BPS, 2008). Oleh karena itu, pengklasifikasian IPMdapat dilakukan dengan pendekatan regresi probit. Dalam penelitian sosial, analisis statistika yang sering digunakan mengarah pada hubungan antara variabel respon dan variabel prediktor dengan data yang sering diamati merupakan data kategorik termasuk data biner. Adapun model yang sering digunakan untuk menganalisis variabel respon berskala biner adalah model probit (Gujarati, 2003, dan Green, 2008).

Adanya perbedaan nilai IPM di suatu wilayah tertentu dengan wilayah yang lain disebabkan oleh adanya perbedaan tingkat kualitas masyarakat/penduduk di wilayah tersebut. Secara data didapati bahwa terdapat kemiripan nilai IPM antar wilayah yang berdekatan secara geografis yang mengakibatkan klasifikasi IPM wilayah yang berdekatan tersebut sama. Hal ini diduga karena adanya dependensi/keterkaitan hubungan antar wilayah.

Penelitian LeSage dan Smith (2002) menjabarkan bahwa model probit sering digunakan untuk menjelaskan variasi dalam pilihan individu yang dapat menjelaskan pengaruh interaksi spasial berdasarkan variasi lokasi spasial dari para pembuat keputusan. Oleh karena itu individu-individu yang berlokasi pada titik yang berdekatan akan cenderung menunjukkan suatu perilaku yang mirip dalam membuat keputusan. Sementara penggunaan data spasial pada regresi linier klasik dapat menyebabkan hasil yang kurang tepat, karena asumsi error yang saling bebas dan homogen tidak terpenuhi. Pada data respon yang berskala biner yang melibatkan aspek keterkaitan antara wilayah satu dengan wilayah yang lain diperlukan metode khusus yang menggabungkan metode regresi probit dengan aspek spasial. Dari penjabaran di atas, maka data IPM dalam penelitian ini dapat didekati dengan metode regresi probit spasial.

Penelitian mengenai regresi probit spasial pernah dilakukan oleh Wang, Iglesias, dan Wooldridge (2009) yang menggunakan data cross section pada variabel respon yang berskala biner dengan metode penaksiran Maximum Likelihood Estimation (MLE). Berdasarkan penelitian tersebut nilai fungsi ln likelihood untuk model probit spasial lebih kecil jika dibandingkan dengan model probit sehingga dapat disimpulkan bahwa model probit spasial lebih baik jika dibandingkan dengan model probit.

Wilayah pulau Jawa terdiri dari 6 provinsi besar di Indonesia, dan mempunyai kabupaten/kota terbanyak di Indonesia yaitu 118 kabupaten/kota. Berdasarkan peringkat IPM tahun 2010, provinsi-provinsi di pulau Jawa masuk dalam 20 besar dibandingkan dengan 33 provinsi di Indonesia, kecuali provinsi Banten menduduki peringkat 23. Peringkat pertama IPM nasional diduduki oleh provinsi DKI Jakarta, kemudian provinsi DIY dengan peringkat 4, disusul provinsi Jawa Tengah menduduki peringkat 14, sedangkan provinsi Jawa Barat dan Jawa Timur masing-masing menduduki peringkat 15 dan 18 (BPS,2011).

Pada penelitian probit spasial sebelumnya belum dikaji secara rinci tentang penaksiran parameter dan pengujian parameter model, maka kajian utama pada penelitian ini adalah penaksiran dan pengujian parameter model regresi probit spasial dengan mengaplikasikan pada kasus klasifikasi IPM di pulau Jawa. Pada penelitian ini diharapkan penggunaan model regresi probit spasial mampu menghasilkan model klasifikasi IPM yang spesifik di setiap daerah sehingga semakin informatif dan aplikatif sehingga dapat diketahui faktor-faktor yang berpengaruh terhadap klasifikasi IPM di pulau Jawa.

Permasalahan yang diangkat dalam penelitian ini adalah bagaimana mendapatkan penaksiran dan pengujian parameter model regresi probit spasial dengan mengkaji secara rinci dan mengaplikasikan pada kasus klasifikasi IPM di pulau Jawa. 
Jika ditinjau dari segi kelimuan, manfaat penelitian ini adalah untuk meningkatkan wawasan pengetahuan dan keilmuan mengenai metode pemodelan untuk data kualitatif; khususnya model regresi probit spasial. Selain itu, diharapkan penelitian ini dapat memberikan manfaat bagi pemerintah khususnya pemerintah propinsi pulau Jawa yaitu dengan mengetahui faktor-faktor yang mempengaruhi klasifikasi IPM untuk dijadikan acuan dalam mengambil keputusan kebijakan dalam meningkatkan kualitas indeks pembangunan manusia di pulau Jawa.

\section{TEORI DASAR}

\section{Model Regresi Probit}

Menurut Greenberg (1980) analisis probit pertama kali dikemukakan oleh Chester Ittner Bliss pada tahun 1934 yang dalam penelitiannya mengenai pestisida untuk mengendalikan serangga yang hidup pada daun dan buah anggur. Dalam suatu artikel di jurnal Science, Bliss (1934) mengemukakan bahwa istilah probit dalam model regresi probit berasal dari kata probability unit, dengan kata lain model regresi probit merupakan suatu model regresi yang berkatian dengan unitunit probabilitas.

Model regresi probit adalah salah satu model regresi yang dapat digunakan untuk mengetahui pengaruh variabel prediktor terhadap variabel respon yang bersifat biner. Menurut O'Donnel dan Connor (1996), serta Greene (2008) pemodelan regresi probit diawali dengan melihat model sebagai berikut :

$$
Y^{*}=\beta^{T} x+\varepsilon
$$

dimana $Y^{*}$ adalah variabel respon yang merupakan variabel kontinu, $\beta$ adalah vektor parameter koefisien dengan $\beta=\left[\beta_{0}, \beta_{1}, \ldots, \beta_{p}\right], x$ adalah vektor variabel prediktor, dengan $x=$ $\left[1, x_{1}, \ldots, x_{p}\right]^{T}$ dan $\varepsilon$ adalah error yang diasumsikan berdistribusi $N\left(0, \sigma^{2}\right)$. Dengan demikian $E\left(Y^{*}\right)=\beta^{T} x, \quad \operatorname{Var}\left(Y^{*}\right)=\sigma^{2} \quad$ dan $f\left(Y^{*}\right)=\frac{1}{\sqrt{2 \pi \sigma}} \exp \left[-\frac{1}{2 \sigma^{2}}\left(Y^{*}-\beta^{T} x\right)^{2}\right]$ yang dapat dilihat pada gambar berikut.

Dari gambar 1, terlihat bahwa untuk setiap luasan mempunyai probabilitas sebagai berikut:

$$
\begin{aligned}
P\left(Y^{*}>k\right) & =1-P\left(Y^{*} \leq \gamma_{k-1}\right) \\
& =1-\Phi\left(\gamma_{k-1}\right) \\
& =\int_{\gamma_{k-1}}^{\infty} f\left(Y^{*}\right) d Y^{*}
\end{aligned}
$$

kemudian dari persamaan (2) dilakukan transformasi ke dalam bentuk $Z=\frac{Y^{*}-\beta^{T} x}{\sigma}$ dimana $Z \sim N(0,1)$, sehingga (3) menjadi persamaan (4) adalah sebagai berikut:

$$
\begin{aligned}
P\left(Y^{*}>k\right) & =1-P\left(Y^{*} \leq \gamma_{k-1}\right) \\
= & 1-P\left(Z \leq \frac{\gamma_{k-1}-\beta^{T} x}{\sigma}\right) \\
P\left(Y^{*}>k\right) & =1-\Phi\left(\frac{\gamma_{k-1}-\beta^{T} x}{\sigma}\right)
\end{aligned}
$$

dimana $\gamma_{1}, \gamma_{2}, \ldots, \gamma_{\mathrm{k}}$ adalah batasan (threshold) dan $\Phi(\cdot)$ adalah seperti pada (2). Kemudian dilakukan pengkategorian terhadap $Y^{*}$ yaitu untuk $Y^{*} \leq \gamma_{1}$ dikategorikan dengan $Y=1$, untuk $\gamma_{1}<Y^{*} \leq \gamma_{2}$ dikategorikan dengan $Y=2, \ldots$, untuk $\gamma_{k-2}<Y^{*} \leq \gamma_{k-1}$ dikategorikan dengan $Y=k-1, \quad \ldots$, untuk $Y^{*}>\gamma_{k-1}$ dikategorikan dengan $Y=k$, sehingga diperoleh model regresi probit pada persamaan (4).

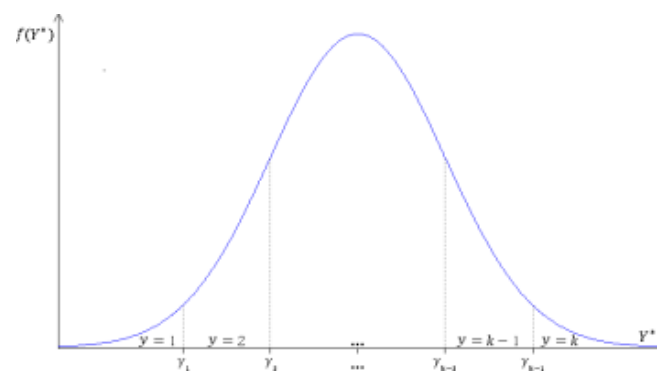

Gambar 1. Grafik Fungsi Distribusi Probabilitas dari $Y^{*}$

Menginterpretasikan model probit pada persamaan (5) digunakan efek marginal (Green, 2008). Efek marginal diperoleh dari turunan probabilitas tiap kategorinya. Efek marginal variabel Xpada model probit adalah sebagai-mana persamaan (4) berikut :

$$
\frac{\partial P(Y=k)}{\partial X_{i}}=\phi\left(\frac{\gamma_{k-1}-\beta^{T} x}{\sigma}\right) \frac{\beta_{i}}{\sigma}
$$

Persamaan (5) menunjukkan besarnya pengaruh variabel $X_{i}$ terhadap $P(Y=k)$. Sehingga untuk mengetahui distribusi model regresi probit pada persamaan (2) dipandang $Y=$ $\left[\begin{array}{lllll}Y_{1} & Y_{2} & Y_{3} & \ldots & Y_{k}\end{array}\right]^{T}$ dimana $Y_{i}=0,1$ untuk $i=$ $1, \ldots, k ; Y_{k}=1-\left(Y_{1}+\cdots+Y_{k-1}\right)$ dan probabilitas untuk $Y=k$ adalah $P(Y=k)=1-[P(Y=1)+$ $\cdots+P(Y=k-1)]$, dengan demikian variabel $Y$ mengikuti distribusi Multinomial yang dapat dituliskan seperti berikut.

$$
\begin{gathered}
Y \sim M[1 ; P(Y=1 \mid x), P(Y=2 \mid x), \\
P, L P(Y=k-1 \mid x)]
\end{gathered}
$$




$$
\begin{aligned}
& P\left[Y_{1}=y_{1}, \ldots, Y_{k-1}=y_{k-1}\right] \\
& =\left\{( \Phi [ \frac { \gamma _ { 1 } - \beta ^ { T } x } { \sigma } ] ) ^ { y _ { 1 } } \left(\Phi\left[\frac{\gamma_{2}-\beta^{T} x}{\sigma}\right]\right.\right. \\
& \left.-\Phi\left[\frac{\gamma_{1}-\beta^{T} x}{\sigma}\right]\right)^{y_{2}} \cdots\left(\Phi\left[\frac{\gamma_{k-1}-\beta^{T} x}{\sigma}\right]\right. \\
& \left.\left.-\Phi\left[\frac{\gamma_{k-2}-\beta^{T} x}{\sigma}\right]\right)^{y_{k-2}}\left(1-\Phi\left[\frac{\gamma_{k-1}-\beta^{T} x}{\sigma}\right]\right)^{y_{k-1}}\right\}
\end{aligned}
$$

\section{Analisis Spasial}

Penelitian yang berkaitan dengan region atau kewilayahan sering disebut dengan spasial. Menurut Tobler (1979) dalam Anselin (1988) mengatakan bahwa segala sesuatu yang saling berpengaruh satu sama lain, yang artinya wilayah yang lebih dekat cenderung akan memberikan pengaruh yang lebih besar dari pada wilayah yang lebih jauh jaraknya. Pada data spasial, seringkali pengamatan di suatu wilayah bergantung pada pengamatan di wilayah lain yang berdekatan (neighboring). Sifat data spasial ada dua macam yaitu spatial dependence yang terjadi akibat adanya dependensi dalam data cross-section dan spatial heterogeneity terjadi akibat adanya perbedaan antara satu wilayah dengan wilayah lainnya (Anselin, 1995).

Anselin (1988) telah mengembangkan beberapa metode spasial dengan menggunakan data cross section. Bentuk umum model regresi spasial adalah sebagai berikut :

$$
\begin{aligned}
& \mathbf{y}=\rho \mathbf{W}_{\mathbf{1}} \mathbf{y}+\mathbf{X} \boldsymbol{\beta}+\mathbf{u} \\
& \mathbf{u}=\lambda \mathbf{W}_{\mathbf{2}} \mathbf{u}+\boldsymbol{\varepsilon}
\end{aligned}
$$

dimana $\boldsymbol{\varepsilon} \sim N\left(0, \sigma^{2} I_{n}\right), \quad \mathbf{y}$ merupakan vektor variabel respon yang berukuran ( $\mathrm{n} \times 1$ ) dan $\mathbf{X}$ adalah matriks variabel prediktor yang berukuran $n \times(k+1)$. $\boldsymbol{\beta}$ adalah parameter koefisien regresi yang berukuran $(k+1) \times 1, \rho$ adalah parameter koefisien spasial lag dari variabel respon, dan $\lambda$ adalah parameter koefisien spasial lag pada error. Adapun $\mathbf{W}_{\mathbf{1}}$ dan $\mathbf{W}_{\mathbf{2}}$ adalah matriks pembobot yang berukuran $(n \times n)$ yang elemen diagonalnya bernilai nol. $\mathbf{u}$ adalah vektor regresi yang saling berkorelasi dengan ukuran ( $\mathrm{n} \times 1)$.

Ada beberapa turunan model yang bisa diperoleh dari model umum pada persamaan (9), yaitu :

Apabila nilai $\rho=0$ dan $\lambda=0$, maka persamaannya menjadi :

$$
\boldsymbol{y}=\boldsymbol{X} \boldsymbol{\beta}+\boldsymbol{\varepsilon}
$$

Persamaan (10) disebut model regresi klasik atau model regresi Ordinary Least Square (OLS) yaitu model regresi yang tidak mempunyai efek spasial.

Apabila nilai $\rho \neq 0$ dan $\lambda=0$, maka persamaannya menjadi :

$\mathbf{y}=\rho \mathbf{W}_{\mathbf{1}} \mathbf{y}+\mathbf{X} \boldsymbol{\beta}+\boldsymbol{\varepsilon} \mathbf{y}=\rho \mathbf{W}_{\mathbf{1}} \mathbf{y}+\mathbf{X} \boldsymbol{\beta}+\boldsymbol{\varepsilon}$
Persamaan (11) disebut sebagai regresi Spatial Lag Model (SLM). Menurut Lesage (1999) istilah lain model ini adalah model Spatial AutoRegressive (SAR).

Apabila nilai $\lambda \neq 0$ dan $\rho=0$, maka persamaannya menjadi :

$$
\begin{aligned}
& \mathbf{y}=\mathbf{X} \boldsymbol{\beta}+\mathbf{u} \\
& \mathbf{u}=\lambda \mathbf{W}_{\mathbf{2}} \mathbf{u}+\boldsymbol{\varepsilon}
\end{aligned}
$$

Persamaan (2.16) disebut sebagai regresi Spatial Error Model (SEM).

Apabila nilai $\rho \neq 0$ dan $\lambda \neq 0$, maka persamaannya menjadi :

$$
\begin{gathered}
\mathbf{y}=\rho \mathbf{W}_{\mathbf{1}} \mathbf{y}+\mathbf{X} \boldsymbol{\beta}+\mathbf{u} \\
\mathbf{u}=\lambda \mathbf{W}_{\mathbf{2}} \mathbf{u}+\boldsymbol{\varepsilon}
\end{gathered}
$$

Persamaan (13) disebut sebagai General Spatial Model, atau Anselin (1988) menyebutnya model Spatial Autoregressive Moving Average (SARMA).

\section{Uji Dependensi Spasial}

Anselin (1988) menyatakan bahwa untuk mengetahui adanya dependensi spasial digunakan dua metode yaitu metode Moran's I dan Lagrange Multiplier (LM). Berikut ini akan dijabarkan mengenai kedua metode tersebut :

\section{Moran's I}

Indeks Moran's I adalah ukuran korelasi antara pengamatan wilayah yang saling berdekatan. Moran's I (selanjutnya dinotasikan I) membandingkan nilai pengamatan di suatu wilayah tertentu dengan nilai pengamatan di wilayah yang lainnya. Menurut Lee dan Wong (2011) indeks Moran's I dapat dihitung dengan persamaan (2.18) dibawah ini :

$$
I=\frac{n \sum_{i=1}^{n} \sum_{j=1}^{n} w_{i j}\left(y_{i}-\bar{y}\right)\left(y_{j}-\bar{y}\right)}{\left(\sum_{i=1}^{n} \sum_{i=1}^{n} w_{i j}\right) \sum_{i=1}^{n}\left(y_{i}-\bar{y}\right)^{2}}
$$

Keterangan :

$\begin{array}{ll}n & \text { : Banyaknya jumlah pengamatan } \\ w_{i j} & \text { : Elemen matriks pembobot spasial } \\ x_{i} & \text { : Nilai pengamatan pada lokasi ke-i } \\ x_{j} & \text { : Nilai pengamatan pada lokasi ke-j } \\ \bar{x} & \text { : Nilai rata-rata pengamatan }\end{array}$

Identifikasi pola persebaran antar wilayah dapat menggunakan kriteria nilai indeks I (Lee, dan Wong, 2001). Jika nilai $\mathbf{I}>\mathbf{I}_{\mathbf{0}}$ maka mempunyai pola mengelompok, dan jika nilai $\mathbf{I}<$ $\mathbf{I}_{\mathbf{0}}$ maka mempunyai pola menyebar (tidak ada autokorelasi), sedangkan nilai $\mathbf{I}<\mathbf{I}_{\mathbf{0}}$ dikatakan memiliki pola menyebar jika $\mathbf{I}_{\mathbf{0}}=-1 /(n-1)$. 


\section{Langrange Multiplier Test (LM Test)}

Langrange Multiplier Test diperoleh berdasarkan asumsi model di bawah $H_{0}$. Ada tiga hipotesis yang diajukan, yaitu :

$$
\begin{array}{ll}
H_{0} \rho=0 ; H_{1}: \rho \neq 0 & \text { (untuk model } \\
& \text { Spatial Lag Model) } \\
& \text { (untuk model } \\
H_{0}: \lambda=0 ; H_{1}: \lambda \neq 0 \quad & \text { Spatial Error } \\
& \text { Model) } \\
H_{0}: \rho, \lambda=0 ; H_{1} \rho, \lambda \neq 0 & \text { (untuk model } \\
& \text { SARMA) }
\end{array}
$$

Digunakan statistik LM test yang mempunyai bentuk :

$$
\begin{aligned}
L M=E^{-1}\left\{\left(R_{y}\right)^{2}\right. & T_{22}-2 R_{y} R_{e} T_{12} \\
& +\left(R_{e}\right)^{2}(D \\
& \left.\left.+T_{11}\right)\right\} \sim \chi_{m}^{2}
\end{aligned}
$$

Dengan $M$ adalah jumlah parameter spasial, untuk $\mathrm{SLM}=1, \mathrm{SEM}=1$, dan SARMA = 2

$$
\begin{aligned}
R_{y} & =\frac{\mathbf{e}^{T} \mathbf{W}_{\mathbf{1}} \mathbf{y}}{\sigma^{2}} \\
R_{e} & =\frac{\mathbf{e}^{T} \mathbf{W}_{\mathbf{2}} \mathbf{e}}{\sigma^{2}} \\
\mathbf{M} & =\mathbf{I}-\mathbf{X}\left(\mathbf{X}^{T} \mathbf{X}\right)^{-1} \mathbf{X}^{T} \\
T_{i j} & =\operatorname{tr}\left\{\mathbf{W}_{\mathbf{i}} \mathbf{W}_{\mathbf{j}}+\mathbf{W}_{\mathbf{i}}^{T} \mathbf{W}_{\mathbf{j}}\right) \\
D & =\sigma^{-2}\left(\mathbf{W}_{\mathbf{1}} \mathbf{X} \boldsymbol{\beta}\right)^{T} \mathbf{M}\left(\mathbf{W}_{\mathbf{1}} \mathbf{X} \boldsymbol{\beta}\right) \\
E & =\left(D+T_{11}\right) T_{22}-\left(T_{12}\right)^{2}
\end{aligned}
$$

Jika matriks pembobot spasialnya sama $\left(\mathbf{W}_{1}=\mathbf{W}_{2}=\mathbf{W}\right)$, maka:

$$
T_{11}=T_{12}=T_{22}=T=\operatorname{tr}\left\{\left(\mathbf{W}^{T}+\mathbf{W}\right) \mathbf{W}\right\}
$$

Tolak $H_{0}$ jika nila $\mathrm{LM}>\chi_{(m)}^{2}$.

\section{Model Regresi Probit Spasial}

Suatu model probit dengan dependensi spasial pertama kali diteliti oleh Mc. Millen (1992) yaitu suatu algoritma EM diperkenalkan untuk menghasilkan suatu dugaan yang konsisten (maksimum likelihood) untuk model tersebut. Akan tetapi model tersebut sangat bergantung pada asymtotic dan membutuhkan sampel yang besar. Alternatif lainnya, diperkenalkan suatu model probit nonspasial dengan pendekatan hirarki bayessian oleh Albert dan Chib (1993) yang dapat diaplikasikan untuk data dengan sampel kecil. LeSage (2000) kemudian memperkenalkan suatu model yang dikembangkan dari model Albert dan Chib dengan mengikutsertakan suatu dependensi spasial antar data.

Model regresi probit spasial merupakan gabungan model regresi probit dan model spasial.

Menurut Anselin (1988) dan dikembangkan lagi oleh Anselin (1996), Anselin dan Bera (1998),
Anselin (2001a) dan Anselin (2001b) bentuk model regresi probit spasial adalah sebagai berikut :

$$
Y^{*}=\rho W y^{*}+X \beta+\varepsilon
$$

dimana $\mathbf{y}^{*}$ adalah vektor variabel laten berukuran ( $\mathrm{n} \times 1$ ), $\mathbf{X}$ adalah matriks kovariat yang berukuran ( $\mathrm{n} \times \mathrm{k}$ ), $\mathbf{W}$ yaitu matriks pembobot berukuran ( $\mathrm{n} \times \mathrm{n})$, dan $\rho$ adalah parameter spasial.

Persamaan (2.21) dapat ditulis dalam bentuk direduksi adalah sebagai berikut :

$$
\begin{gathered}
y^{*}=(I-\rho W)^{-1} X \beta+u \\
u=(I-\rho W)^{-1} \varepsilon
\end{gathered}
$$

Link variabel laten $\mathbf{y}^{*}$ untuk pengamatan biner, $y$, melalui persamaan berikut

$$
y= \begin{cases}0, & \text { jika } y^{*} \leq \gamma_{1} \\ 1, & \text { jika } \gamma_{1}<y^{*} \leq \gamma_{2}\end{cases}
$$

Probabilitas untuk pengamatan ke-i adalah salah satunya dapat dihitung sebagai berikut :

$$
\begin{aligned}
P(Y=k) & =P\left(Y^{*}>\gamma_{k-1}\right) \\
& =1-P\left(Y^{*} \leq \gamma_{k-1}\right) \\
& =1-P\left(Z \leq \frac{\gamma_{k-1}-\rho W y^{*}-X \beta}{\sigma}\right) \\
& =1-\Phi\left(\frac{\gamma_{k-1}-\rho W y^{*}-X \beta}{\sigma}\right)
\end{aligned}
$$

\section{Indeks Pembangunan Manusia (IPM)}

Salah satu alat ukur yang dianggap dapat merefleksikan status pembangunan manusia adalah Indeks Pembangunan Manusia (IPM) atau Human Development Index (HDI). UNDP sejak tahun 1990 menggunakan IPM untuk mengukur perkembangan pembangunan manusia. IPM merupakan suatu indeks komposit yang mencakup tiga dimensi pokok pembangunan manusia yang dinilai mencerminkan status kemampuan dasar penduduk yaitu kesehatan, pencapaian pendidikan, dan standar hidup layak. Ketiga dimensi tersebut memiliki pengertian sangat luas karena terkait banyak faktor. Dimensi kesehatan yang diukur dari angka harapan hidup, dimensi pencapaian pendidikan yang diukur dari rata-rata lama sekolah dan angka melek huruf, sedangkan dimensi standar hidup layak yang diindikasikan dengan logaritma normal dari produk domestik bruto perkapita penduduk dalam paritas daya beli (BPS, 2008).

IPM dapat mengetahui kondisi pembangunan di daerah dengan alasan :

a) IPM menjadi indikator penting untuk mengukur keberhasilan dalam pembangunan kualitas manusia. 
b) IPM menjelaskan tentang bagaimana manusia mempunyai kesempatan untuk mengakses hasil dari proses pembangunan, sebagai bagian dari haknya seperti dalam memperoleh pendapatan, kesehatan, pendidikan, dan kesejahteraan.

c) IPM digunakan sebagai salah satu ukuran kinerja daerah, khususnya dalam hal evaluasi terhadap pembangunan kualitas hidup masyarakat/penduduk.

d) IPM belum tentu mencerminkan kondisi sesungguhnya namun untuk saat ini IPM merupakan satu-satunya indikator yang dapat digunakan untuk mengukur pembangunan kualitas hidup manusia.

Salah satu alat ukur yang dianggap dapat merefleksikan status pembangunan manusia adalah Human Development Index (HDI) atau IPM. IPM merupakan sauatu indeks komposit yang mencakup tiga bidang pembangunan manusia yang dianggap sangat mendasar yaitu usia angka harapan hidup, tingkat pendidikan, dan standar hidup layak (BPS, 2009).

\section{Angka Harapan Hidup}

Pembangunan manusia harus lebih mengupayakan agar penduduk dapat mencapai usia hidup yang panjang dan sehat. Kemampuan untuk bertahan hidup lebih lama yang akan dijalani oleh bayi yang baru lahir pada suatu tahun tertentu yang diukur dengan angka harapan hidup pada saat lahir (life expectacy at birth). Angka harapan hidup dapat digunakan untuk mengevaluasi kinerja pemerintah dalam meningkatkan kesejahteraan penduduk khususnya meningkatkan derajat kesehatan penduduk. Semakin tinggi angka harapan hidup suatu wilayah, mengindikasikan bahwa semakin tinggi kualitas fisik penduduk pada wilayah tersebut (BPS, 2008).

\section{Tingkat Pendidikan}

Komponen pendidikan diukur dengan angka melek huruf dan rata-rata lama sekolah. Sebagai catatan, UNDP dalam publikasi tahunan HDR sejak 1995 menggunakan indikator partisipasi sekolah dasar, menengah, dan tinggi sebagai pengganti rata-rata lama sekolah karena sulitnya memperoleh data rata-rata lama sekolah secara global. Indikator angka melek huruf diperoleh dari variabel membaca dan menulis, sedangkan indikator rata-rata lama sekolah dihitung dengan menggunakan dua variabel secara simultan, yaitu tingkat/kelas yang sedang/pernah dijalani dan jenjang pendidikan tertinggi yang ditamatkan (BPS, 2008).

\section{Standar Hidup Layak}

Dimensi ketiga IPM adalah standar hidup layak (decent living standard) yang dapat mengindikasikan tingkat kesejahteraan masyarakat atau dikenal dengan istilah kemampuan daya beli daya masyarakat/ penduduk. Sebagai catatan, UNDP menggunakan indikator PDRB per kapita riil yang telah disesuaikan sebagai ukuran komponen tersebut hal ini dikarenakan tidak tersedia indikator lain yang lebih baik untuk keperluan perbandingan antar negara. Sementara BPS dalam menghitung standar hidup layak menggunakan rata-rata pengeluaran per kapita riil yang disesuaikan dengan formula Atkinson (BPS, 2008).

Indeks Pembangunan Manusia (IPM) menjadi indikator penting untuk mengukur keberhasilan dalam upaya membangun kualitas hidup manusia yang dapat menjelaskan bagaimana penduduk dapat mengakses hasil pembangunan dalam memperoleh penadapatan, kesehatan, dan pendidikan. Kualitas sumber daya manusia suatu daerah sangat tergantung dari tingkat pendidikan penduduknya, karena pendidikan yang berkualitas dapat menghasilkan output pendidikan yang berkualitas. Apabila tingkat pendidikan masyarakat rendah, kapabilitasnya juga rendah. Hal ini akan berpengaruh terhadap rendahnya kemampuan untuk menangkap peluang, sehingga akan berakibat pada kemiskinan (Naja, 2006).

Kajian mengenai indikator IPM telah banyak dilakukan diantaranya penelitian yang dilakukan oleh Wachid (2000) tentang faktorfaktor yang mempengaruhi kualitas hidup manusia dengan analisis regresi berganda. Hasil penelitian tersebutadalah faktor-faktor yang mempengaruhi kualitas hidup manusia adalah rata-rata lama sekolah, angka buta huruf, angka kematian bayi, angka kematian ibu, tingkat pengangguran terbuka dan persentase penduduk miskin. Dalam penelitian Setiawan (2004) mengungkapkan bahwa faktor lokasi tempat tinggal (perkotaan atau pedesaan) cenderung berpengaruh terhadap tingkat pendidikan dan menunjukkan hubungan yang tinggi dengan tingkat pendapatan dan pengeluaran.

Sementara penelitian indikator IPM juga dilakukan oleh Suanita (2006), hasil penelitiannya menyimpulkan bahwa faktor-faktor yang mempengaruhi rata-rata pengeluaran konsumsi per kapita adalah PDRB perkapita, rasio ketergantungan penduduk dan peranan sektor pertanian dalam PDRB. Secara umum pengeluaran konsumsi setiap anggota rumah tangga dibagi menjadi dua kelompok yaitu pengeluaran konsumsi untuk makanan dan bukan makanan. Menurut BPS (2008) rasio ketergantungan 
merupakan gabungan indikator Rasio Ketergantungan Anak (RKA) dan Rasio Ketergantungan Usia Lanjut (RKL) yang menunjukkan total rasio ketergantungan penduduk usia tidak produktif pada usia produktif. Kegunaan RKA adalah menunjukkan besarnya beban tanggungan anak bagi penduduk usia di suatu daerah pada suatu waktu tertentu sedangkan kegunaan RKL menggambarkan besarnya beban tanggungan penduduk usia lanjut bagi penduduk usia produktif. Secara umum dapat menggambarkan beban tanggungan ekonomi kelompok usia produktif (penduduk usia 15-65 tahun) terhadap kelompok usia tidak produktif (penduduk usia 0-14 tahun dan usia si atas 65 tahun). Sehingga semakin besar rasio ketergantungan akan menyebabkan pengeluaran konsumsi per kapita semakin kecil, karena meningkatnya jumlah tanggungan menyebabkan jumlah pendapatan yang diperoleh seseorang akan dibagi kepada lebih banyak orang yang juga berdampak pada tingkat pendidikan dan kesehatan (Suanita, 2006).

Menurut Zairin (2006) dalam penelitiannya yang menggunakan rumus regresi sederhana ada korelasi positif antara alokasi belanja dalam APBD dengan pencapaian IPM. Semakin besar alokasi belanja dalam APBD yang relevan dengan komponen pembentuk IPM, maka semakin tinggi tingkat pencapaian IPM. itu, salah satu upaya untuk meningkatkan pencapaian IPM yaitu meningkatkan besaran alokasi belanja dalam APBD untuk komponen yang terkait secara langsung maupun secara tidak langsung dengan aspek pendidikan, kesehatan dan kemampuan daya beli masyarakat/penduduk. Besarnya pengeluaran sektor industri terhadap PDRB akan berpengaruh terhadap pengeluaran konsumsi penduduk, mengingat daerah yang maju sektor industrinya akan meningkatkan tingkat pendidikan dan kesejahteraan masyarakatnya (Suanita, 2006).

Sementara semakin tinggi angka keluhan kesehatan maka akan mengurangi angka harapan hidup sehingga mengakibatkan penurunan IPM suatu daerah (BPS, 2009). Tingkat pengangguran terbuka adalah salah satu indikator kemampuan daya beli masyarakat. Sedikitnya jumlah pengangguran mengindikasikan bahwa meningkatkan nilai daya beli masyarakat (BPS, 2010). Rata-rata umur kawin pertama wanita mempunyai pengaruh yang positif terhadap nilai IPM. Semakin tinggi rata-rata umur kawin pertama wanita di suatu provinsi menyebabkan nilai IPM di provinsi tersebut semakin tinggi (BPS, 2008).

\section{METODE PENELITIAN}

Data yang digunakan dalam penelitian ini adalah data sekunder yang yang diperoleh dari Badan Pusat Statistik (BPS) yaitu data yang diambil dari publikasi maupun data dari hasil survei. Data publikasi yang diambil adalah data publikasi provinsi dalam angka tahun 2010 dan publikasi Laporan Pembangunan Manusia Indonesia tahun 2010 sedangkan data survei yang diambil adalah data Survei Sosial Ekonomi Nasional (SUSENAS) tahun 2010 untuk Pulau Jawa. Unit pengamatan pada penelitian ini adalah 118 kabupaten/kota di Pulau Jawa.

Adapun variabel yang diamati dalam penelitian ini adalah terdiri dari satu variabel respon dan sembilan variabel prediktor. Variabel yang berperan sebagai veriabel respon ( $\mathrm{Y}$ ) adalah Indeks Pembangunan Manusia (IPM). Variabel respon ini bersifat kategorik. Menurut BPS (2008) IPM dibagi menjadi empat kategori yaitu sebagai berikut :

$0=$ Rendah, jika IPM $\leq 50$

$1=$ Menengah rendah jika $50<\mathrm{IPM} \leq 66$

$2=$ Menengah tinggi jika $66<$ IPM $\leq 80$

$3=$ Tinggi jika IPM $>80$

Pada penelitian ini jika IPM dibagi sesuai dengan ketentuan BPS yaitu empat kategori maka terdapat beberapa kategori yang kosong yaitu pada kategori rendah dan tinggi. Oleh karena itu pada penelitian ini menggunakan dua kategori yaitu ketegori menengah rendah dan menengah tinggi sesuai dengan kategori yang ada di BPS, pembagian kategori tersebut adalah sebagai berikut :

$0=$ Menengah rendah, jika IPM $\leq 66$

$1=$ Menengah tinggi jika $66<\mathrm{IPM} \leq 80$

Berikut merupakan beberapa variabel prediktor yang akan dilibatkan dalam penelitian ini adalah sebagai berikut:

\section{Persentase penduduk yang tinggal di perkotaan (X1).}

Persentase penduduk yang tinggal di perkotaan adalah jumlah penduduk yang tinggal di daerah perkotaan dalam jangka waktu tertentu.

\section{Persentase penduduk yang berpendidikan di atas SLTP (X2)}

Penduduk yang berpendidikan diatas SLTP adalah penduduk yang telah menamatkan pendidikan setingkat SLTP atau jenjang pendidikan yang lebih tinggi. 


\section{Rata-rata pendapatan per kapita (X3)}

Pendapatan per kapita (per capita income) adalah pendapatan rata-rata penduduk suatu negara pada suatu periode tertentu, yang biasanya satu tahun.

\section{Rasio ketergantungan penduduk (X4)}

Rasio ketergantungan menunjukkan beban tanggungan penduduk usia produktif (15-64 tahun) terhadap penduduk usia muda (kurang dari 15 tahun) dan penduduk usia tua (65 tahun atau lebih) (BPS, 2008).

\section{Peranan sektor industri dalam PDRB (X5)}

PDRB merupakan jumlah nilai tambah atas barang dan jasa yang dihasilkan oleh berbagai unit produksi di suatu wilayah dalam jangka waktu tertentu.

\section{Persentase penduduk miskin (X6)}

Penduduk Miskin adalah penduduk yang tidak mempunyai kemampuan dalam memenuhi kebutuhan dasar untuk kehidupan yang layak, baik kebutuhan dasar makanan maupun kebutuhan dasar bukan makanan (Urip, 2007).

\section{Persentase penduduk yang mengalami keluhan kesehatan (X7)}

Semakin tinggi angka keluhan kesehatan maka akan mengurangi angka harapan hidup sehingga mengakibatkan penurunan IPM suatu daerah (BPS, 2009).

\section{Tingkat pengangguran terbuka (X8)}

Tingkat pengangguran terbuka adalah salah satu indikator kemampuan daya beli masyarakat. Sedikitnya jumlah pengangguran mengindikasikan bahwa meningkatkan nilai daya beli masyarakat (BPS, 2010).

\section{Rata-rata umur kawin pertama wanita (X9)}

Rata-rata umur kawin pertama wanita mempunyai pengaruh yang positif terhadap nilai IPM. Semakin tinggi rata-rata umur kawin pertama wanita di suatu provinsi menyebabkan nilai IPM di provinsi tersebut semakin tinggi (BPS, 2008).

Pulau Jawa terdiri dari 84 Kabupaten dan 34 Kota yang menyebar di enam provinsi (lihat Tabel 3.3). Secara geografis, letak dari 118 Kabupaten/Kota di Pulau Jawa tersebut masingmasing tidak saling simetris. Peta digital Pulau Jawa digunakan sebagai dasar pembentukan penimbang spasial menggunakan metode queen contiguity, wilayah-wilayah tersebut saling berbatasan sisi atau sudut yang dianggap saling mempengaruhi.

Tabel 1. Jumlah Kabupaten/Kota di Pulau Jawa Menurut Provinsi

\begin{tabular}{llll}
\hline Provinsi & Kabupaten & Kota & Jumlah \\
\hline DKI Jakarta & 1 & 5 & 6 \\
Jawa Barat & 17 & 9 & 26 \\
Jawa Tengah & 29 & 6 & 35 \\
Daerah Istimewa & 4 & 1 & 5 \\
Yogyakarta & & 9 & 38 \\
Jawa Timur & 29 & 4 & 8 \\
Banten & 4 & 34 & 118 \\
Jumlah & 84 & \\
\hline
\end{tabular}

Sumber : Badan Pusat Statistik, 2011

Alasan penggunaan metode queen contiguityadalah adanya dua wilayah yang saling bersinggungan antara Kabupaten Sleman Provinsi Daerah Istimewa Yogyakarta dengan Kabupaten Boyolali Provinsi Jawa Tengah. Metode dan tahapan analisis yang akan digunakan untuk mencapai tujuan penelitian ini adalah sebagai berikut :

1. Menentukan bentuk umum model regresi probit spasial.

2. Menyusun langkah-langkah estimasi parameter metode MCMC sebagai berikut:

a) Menentukan teknik pembangkitan angka random yang berdistribusi normal terpotong untuk melengkapi data yang tersensor.

b) Menentukan bentuk persamaan likelihood dari model regresi spasial

c) Menentukan probabilita prior dari masing-masing parameter yang saling independen berdasarkan hasil studi literatur

d) Menentukan distribusi posterior bersama dari model regresi spasial

e) Menentukan distribusi posterior bersyarat dari masing-masing parameter dengan syarat parameter lainnya diketahui.

Untuk menyusun algoritma pemrograman dalam rangka pembentukan model regresi probit spasial, dilakukan langkah-langkah sebagai berikut:

1. Menyusun algoritma dan pemrograman untuk pengujian efek korelasi spasial dan pengujian heteroskedastisitas dari model regresi probit spasial yang akan dibentuk.

2. Menyusun algoritma Gibbs sampler untuk estimasi parameter model regresi probit spasial dari distribusi posterior bersyarat 
yang telah terbentuk pada langkah sebelumnya.

3. Menyusun algoritma Metropolis within Gibbs untuk estimasi parameter model regresi probit spasial ( atau ) dari distribusi posterior bersyarat yang telah terbentuk pada langkah sebelumnya.

4. Menyusun algoritma Slice Sampling untuk membangkitkan angka random yang berdistribusi normal terpotong dalam rangka melengkapi data yang tersensor.

\section{DISKUSI / PEMBAHASAN}

Persebaran IPM di Pulau Jawa menurut kabupaten/kota disajikan pada Gambar 1.1. Kabupaten/kota yang memiliki nilai klasifikasi IPM terendah sebesar 59.70 yaitu terdapat di kabupaten Sampang dan tertinggi sebesar 79.52 terdapat di Kota Yogyakarta. Degradasi warna yang terdapat pada gambar menunjukkan klasifikasi IPM.

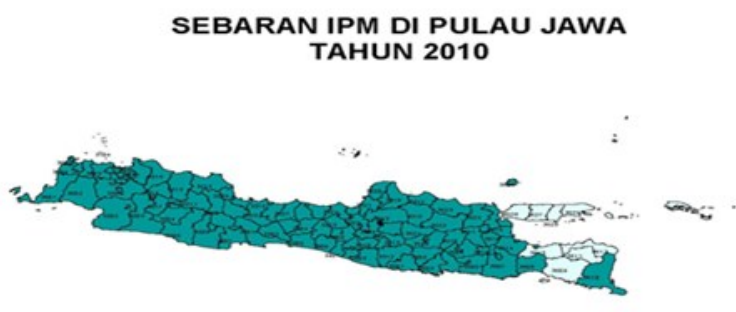
2010

Berdasarkan Tabel 2 dapat diketahui bahwa 6.78\% kabupaten/kota di Pulau Jawa tergolong dalam wilayah yang memiliki nilaiklasifikasi IPM yang menengah rendah. Sebagian besar kabupaten/kota di Pulau Jawa tergolong dalam wilayah yang memiliki nilai klasifikasi IPM menengah tinggi yaitu mencapai 93.22\%,

Tabel 2. Persentase Kelompok Kabupaten/Kota Berdasarkan Klasifikasi IPM di Pulau Jawa

\begin{tabular}{|l|r|r|}
\hline \multicolumn{1}{|c|}{$\begin{array}{c}\text { Klasifikasi } \\
\text { IPM }\end{array}$} & \multicolumn{2}{c|}{ Pulau Jawa } \\
\cline { 2 - 3 } & Jumlah & Pers entase \\
\hline Menengah Rendah & 8 & 6.78 \\
\hline Menengah Tinggi & 110 & 93.22 \\
\hline Total & $\mathbf{1 1 8}$ & $\mathbf{1 0 0 . 0 0}$ \\
\hline
\end{tabular}

Eksplorasi data statistika deskriptif di gunakan untuk mengetahui perbedaan karakteristik antara kelompok wilayah yang memiliki nilai klasifikasi IPM rendah, menengah dan tinggi. Karakteristik variabel prediktor yang diduga berpengaruh terhadap klasifikasi IPM disajikan pada Tabel 3 .

Tabel 3. Statistik Deskriptif Variabel Prediktor

\begin{tabular}{|c|l|r|r|r|r|}
\hline \multirow{2}{*}{ Variabel } & \multirow{2}{*}{ Klasifikasi IPM } & \multicolumn{4}{|c|}{ Deskriptif } \\
\cline { 2 - 6 } X1 & Rata-rata & Std Dev & \multicolumn{1}{c|}{ Min } & \multicolumn{1}{c|}{ Maks } \\
\hline \multirow{2}{*}{ X2 } & Menengah Rendah & 28.79 & 11.73 & 12.92 & 44.32 \\
\cline { 2 - 6 } & Menengah Tinggi & 60.22 & 30.67 & 9.28 & 100.00 \\
\cline { 2 - 6 } & Menengah Rendah & 22.64 & 4.77 & 14.01 & 27.52 \\
\hline \multirow{2}{*}{ X3 } & Menengah Tinggi & 42.38 & 13.73 & 20.14 & 70.18 \\
\cline { 2 - 6 } & Menengah Rendah & 10.33 & 2.78 & 6.04 & 15.33 \\
\hline \multirow{2}{*}{ X4 } & Menengah Rendah & 47.89 & 5.14 & 42.01 & 56.56 \\
\cline { 2 - 6 } & Menengah Tinggi & 48.45 & 5.68 & 35.69 & 63.23 \\
\hline \multirow{2}{*}{ X5 } & Menengah Rendah & 8.14 & 6.72 & 1.03 & 18.83 \\
\cline { 2 - 6 } & Menengah Tinggi & 22.08 & 18.22 & 0.31 & 76.94 \\
\hline \multirow{2}{*}{ X6 } & Menengah Rendah & 22.53 & 6.42 & 13.27 & 32.47 \\
\cline { 2 - 6 } & Menengah Tinggi & 12.64 & 5.27 & 1.67 & 24.58 \\
\hline \multirow{2}{*}{ X7 } & Menengah Rendah & 2.80 & 1.39 & 1.60 & 5.79 \\
\cline { 2 - 6 } & Menengah Tinggi & 7.76 & 3.87 & 0.87 & 19.84 \\
\hline \multirow{2}{*}{ X8 } & Menengah Rendah & 17.00 & 0.70 & 16.00 & 17.81 \\
\cline { 2 - 6 } & Menengah Tinggi & 19.00 & 1.31 & 17.00 & 22.15 \\
\hline
\end{tabular}

Setelah mengetahui karakteristik dari vaeriabel prediktor yang diduga berpengaruh terhadap klasifikasi IPM di Pulau Jawa maka langkah selanjutnya adlah menguji ada atau tidaknya multikolinearitas diantara variabelvariabel prediktor. Kriteria yang digunakan untuk memeriksa multikolinearitas antar variabel adalah dengan menggunakan nilai Variance Inflation Factor (VIF) pada variabel-variabel prediktor. Nilai VIF yang lebih besar dari 10 menunjukkan adanya kolinearitas antar variabel prediktor.

Tabel 4. Nilai VIF Variabel Prediktor

\begin{tabular}{|c|c|c|}
\hline Variabel & VIF & Keterangan \\
\hline X1 & 4,844 & Tidak ada multikolinearitas \\
\hline X2 & 14,05 & Ada multikolinearitas \\
\hline X3 & 1,318 & Tidak ada multikolinearitas \\
\hline X4 & 2,965 & Tidak ada multikolinearitas \\
\hline X5 & 1,316 & Tidak ada multikolinearitas \\
\hline X6 & 2,649 & Tidak ada multikolinearitas \\
\hline X7 & 2,303 & Tidak ada multikolinearitas \\
\hline X8 & 5,415 & Tidak ada multikolinearitas \\
\hline
\end{tabular}

Berdasarkan Tabel 4 terlihat bahwa ada satu variabel prediktor yang mempunyai nilai VIF lebih dari 10 yaitu variabel persentase penduduk yang berpendidikan di atas SLTP (X2). Karena terdapat multikolinearitas antar variabel prediktor, maka untuk memodelkan data klasifikasi IPM di Pulau Jawa diperlukan metode Backward Elimination untuk mengatasi adanya multikolinearitas.

\section{Identifikasi Pola Hubungan Antara variabel Prediktor dan variabel Respon}

Langkah awal dalam proses penyusunan model regresi probit spasial dilakukan identifikasi 
pola hubungan antara variabel prediktor dan variabel respon melalui analisis korelasi dan diagram pencar.

Berdasarkan Tabel 4.3 dapat diketahui bahwa hasil pengujian dengan menggunakan $\alpha=$ $5 \%$ diperoleh kedelapan variabel prediktor, yaitu persentase penduduk yang tinggal di perkotaan (X1), persentase penduduk yang berpendidikan di atas SLTP (X2), rasio ketergantungan (X3), peranan sektor industri dalam PDRB (X4), persentase penduduk miskin (X5), persentase penduduk yang mengalami keluhan kesehatan (X6), tingkat pengangguran terbuka (X7), dan rata-rata umur kawin pertama wanita (X8) memiliki hubungan yang nyata terhadap IPM (Y).

Tabel 4.3 Korelasi Antara Variabel Prediktor dan Variabel Respon

\begin{tabular}{|c|c|c|c|}
\hline $\begin{array}{c}\text { Variabel } \\
\text { Prediktor }\end{array}$ & $\begin{array}{c}\text { Koefisien } \\
\text { Korelasi }\end{array}$ & $\begin{array}{c}\text { P- } \\
\text { value }\end{array}$ & Keterangan \\
\hline $\mathrm{X} 1$ & 0.736 & 0.000 & Ada korelasi \\
\hline $\mathrm{X} 2$ & 0.873 & 0.000 & Ada korelasi \\
\hline $\mathrm{X} 3$ & -0.288 & 0.002 & Ada korelasi \\
\hline $\mathrm{X} 4$ & -0.506 & 0.000 & Ada korelasi \\
\hline $\mathrm{X} 5$ & 0.237 & 0.010 & Ada korelasi \\
\hline $\mathrm{X} 6$ & -0.666 & 0.000 & Ada korelasi \\
\hline $\mathrm{X} 7$ & 0.380 & 0.000 & Ada korelasi \\
\hline $\mathrm{X} 8$ & 0.830 & 0.000 & Ada korelasi \\
\hline
\end{tabular}

Terdapat lima variabel prediktor yang berkorelasi positif terhadap IPM yaitu X1, X2, X5, X7, dan X8. Korelasi positif ini berarti bahwa jika terjadi peningkatan pada variabel X1, X2, X5, X7, dan X8 maka akan mengakibatkan semakin tingginya nilai IPM begitu juga sebaliknya. Sementara itu variabel X3, X4 dan X6 berkorelasi negatif yang berarti bahwa jika terjadi penurunan pada variabel tersebut maka akan berakibat pada peningkatan nilai IPM.

\section{Nilai Moran's I}

Langkah berikutnya untuk megidentifikasi adanya dependensi spasial pada IPM digunakan nilai Moran's I. berdasarkan hasil yang telah diperoleh dengan menggunakan software Matlab menunjukkan nilai Moran's I sebesar 0.3110. Apabila dibandingkan dengan I0 yang bernilai 0.0288 maka Moran's I pada IPM memiliki nilai yang lebih tinggi. Hal ini mengindikasikan bahwa IPM di Pulau Jawa menunjukkan pola mengelompok dan memiliki karakteristik pada wilayah yang berdekatan.

\section{Pengujian Model Spasial}

Pengujian model spasial pada penelitian ini menggunakan Lagrange Multiplier dan Robust Lagrange Multiplier. Hasil pengujian yang diperoleh digunakan untuk mengetahui model spasial yang sesuai untuk memodelkan IPM di Pulau Jawa. Berdasarkan hasil yang telah diperoleh dari software Matlab untuk masingmasing pengujian adalah sebagai berikut :

\section{Lagrange Multiplier Lag}

Lagrange Multiplier lag digunakan untuk mengetahui dependensi spasial lag pada IPM di Pulau Jawa. Hipotesis yang digunakan adalah sebagai berikut :

$$
\begin{array}{ccc}
\text { H0 } & : \quad \rho=0 \text { (tidak adanya dependensi } \\
& \text { spasial autoregressive dalam model) } \\
\text { H1 } & : \quad \rho \neq 0 \quad \text { (ada dependesi spasial } \\
& \\
& \text { autoregressive dalam model) }
\end{array}
$$

Berdasarkan hasil perhitungan diperoleh nilai LM-lag adalah 45.9881 yang lebih besar dari nilai Chi Square dengan derajat bebas satu yaitu 3.841. Hal ini diperkuat dengan nilai $\mathrm{p}$-value sebesar 0 yang lebih kecil dari $\alpha=5 \%$ sehingga tolak H0. Dengan demikian dapat disimpulkan bahwa terdapat dependensi spasial lag dalam memodelkan IPM.

\section{Lagrange Multiplier Error}

Lagrange Multiplier error digunakan untuk mengetahui adanya dependensi error pada pemodelan IPM di Pulau Jawa. Hipotesis yang digunakan adalah sebagai berikut :

$$
\begin{array}{ll}
\text { H0 }: & \lambda=0 \text { (tidak ada dependensi error } \\
& \text { spasial) } \\
\text { H1 }: \quad \lambda \neq 0 \text { (ada dependensi error spasial) }
\end{array}
$$

Nilai LM error yang dihasilkan dari software Matlab adalah sebesar 20.9876 yang lebih besar jika dibandingkan dengan nilai Chi Square dengan derajat bebas satu yaitu 3.841. Hal ini diperkuat dengan nilai $p$-value sebesar 0 yang lebih kecil dari $\alpha=5 \%$ sehingga tolak H0. Dengan demikian dapat disimpulkan bahwa terdapat dependensi spasial error.

Berdasarkan hasil pengujian Lagrange Multiplier, baik koefisien spasial lag maupun koefisien spasial error signifikan pada $\alpha=5 \%$. Oleh karena itu, untuk mengetahui model spasial apa yang sesuai untuk memodelakn IPM di Pulau Jawa maka digunakan pengujian Robust Lagrange Multiplier.

\section{Robust Lagrange Multiplier Lag}

Pengujian Robust lagrange Multiplier lag digunakan untuk mengetahui adanya dependensi spasial lag dengan asumsi bahwa koefisien spasial error tidak bernilai nol. 
Hipotesis yang digunakan adalah sebagai berikut :

H0 $: \rho=0$ dan $\lambda=0$

H1 $: \rho \neq 0$ dan $\lambda \neq 0$

Berdasarkan hasil perhitungan diperoleh nilai LM-lag adalah 25.974 yang lebih besar jika dibandingkan dengan nilai Chi Square dengan derajat bebas satu yaitu 3.841. Hal ini diperkuat dengan nilai p-value sebesar 0 yang lebih kecil dari $\alpha=5 \%$ sehingga tolak H0. Dengan demikian dapat disimpulkan bahwa terdapat dependensi spasial lag pada saat koefisien spasial error tidak sama dengan nol. Oleh karena itu, untuk memodelkan IPM di Pulau Jawa mengikuti model Spatial Autoregressive (SAR).

\section{Roburt lagrange Multiplier Error}

Pengujian Robust Lagrange Multiplier error digunakan untuk mengetahui adanya dependensi spasial error dengan asumsi bahwa koefisien spasial lag tidak bernilai nol. Hipotesis yang digunakan adalah sebagai berikut :

$$
\begin{array}{ll}
\text { H0 } & : \rho \neq 0 \text { dan } \lambda=0 \\
\text { H1 } & : \rho \neq 0 \text { dan } \lambda \neq 0
\end{array}
$$

Berdasarkan hasil perhitungan diperoleh nilai Robust lagrange Multiplier error adalah 0.8669 yang lebih kecil jika dibandingkan dengan nilai Chi Square dengan derajat bebas satu yaitu 3.841. Hal ini diperkuat dengan nilai p-value sebesar 0 yang lebih kecil dari $\alpha=5 \%$ sehingga gagal tolak Ho. Dengan demikian dapat disimpulkan bahwa tidak terdapat dependensi spasial error pada saat koefisien spasial lag tidak sama dengan nol.

\section{Regresi Probit Spasial}

Tabel 5 Hasil Estimasi MCMC Parameter Model Regresi Probit Spasial Lag

\begin{tabular}{|l|l|l|}
\hline Variabel & Estimasi & $\operatorname{Pr}(>|\mathrm{z}|)$ \\
\hline Konstan & -19.73480 & 0.01062 \\
\hline X6 & -0.157550 & 0.01007 \\
\hline X8 & 1.3104200 & 0.00298 \\
\hline Rho & 0.3953000 & 0.00666 \\
\hline
\end{tabular}

Berdasarkan hasil tabel 5, variabel yang signifikan terhadap model regresi probit spasial adalah X6 dan X8. Sehingga variabel prediktor yang berpengaruh pada klasifikasi IPM di Pulau Jawa adalah persentase penduduk yang mengalami keluhan kesehatan (X6), dan rata-rata umur kawin pertama wanita (X8).

\section{PENUTUP}

Metode estimasi parameter yang digunakan pada probit spasial adalah teknik Markov Chain Monte Carlo (MCMC) dengan algoritma Gibbs Sampler pendekatan inferensia Bayesia, atau disingkat MCMC Gibss sampler. Variabel-variable yang mempengaruhi klasifikasi IPM di Pulau Jawa adalah Persentase penduduk yang mengalami keluhan kesehatan (X6), dan Rata-rata umur kawin pertama wanita (X8).

Berdasarkan hasil penelitian yang telah diperoleh, pengembangan lebih lanjut dapat dilakukan dengan menggunakan Highest Posterior Density (HPD) dan Bayes Faktor sebagai metode pengujian parameter dan model. Penelitian ini masih menggunakan matriks pembobot queen contiguity, sehingga pada penelitian selanjutnya dapat dikembangkan menggunakan matriks pembobot lain, misalnya pembobot jarak. Lebih lanjut, metode MCMC Gibbs sampler untuk pemodelan regresi probit spasial ini dapat digunakan untuk data dan kasus lain yang lebih aplikatif.

\section{UCAPAN TERIMAKASIH}

Pada penelitian ini saya ucapkan terima kasih kepada BPS Pusat Jakarta atas data yang telah diberikan dalam menunjang kebutuhan data di penelitian ini. Kepada dosen pembimbing, keluarga, dan teman-teman yang telah memberikan dukungan dan doa kepada saya dalam menyusun dan menyelesaikan penelitian ini.

\section{REFERENSI}

[1] Agresti, Alan (2002). Categorical Data Analysis, Second Edition. John Wiley \& Sond, INC., New York.

[2] Anselin, L. (1988). Spatial Econometrics : Methods and Models. Dordrecht : Kluwer Academic Publishers.

[3] Anselin, L. (2001a). Spatial Econometrics in Baltagi, Badi (ed.) Companion To Econometrics, forthcoming, 1-30.

[4] Anselin, L. (2001b). Rao's Score Test in Spatial Econometrics. Journal of Statistical Planning and Inference, forthcoming, 1-32.

[5] Anselin, L., A.K.Bera, R. Florax \& M.J.Yoon. (1995). Simple Diagnostic Tests For Spatial Dependence. Regional Science \& Urban Economics 26, 77-104. 
[6] Anselin, L., A.K.Bera, R. Florax. (1998). Spatial Dependence in Linear Regression Models With Introduction to Spatial Econometrics, in A. Ullah and D. Giles (eds.), Handbook of Applied Econometrics Statistics. New York, 237-289.

[7] Arianti, P.T.S., (2009). Pengelompokan Kecamatan Di Kabupaten Probolinggo Berdasarkan Indeks Pembangunan Manusia Dengan Cluster Analysis. Skripsi Jurusan Statisyika FMIPA ITS. Surabaya

[8] BPS., (2008). Indeks Pembangunan Manusia 2006-2007. BPS, Jakarta.

[9] _ ., (2009). Indeks Pembangunan Manusia 2007-2008. BPS, Jakarta.

[10] _ ., (2010). Indeks Pembangunan Manusia 2008-2009. BPS, Jakarta.

[11] _ ., (2011). Indeks Pembangunan Manusia 2009-2010. BPS, Jakarta.

[12] Diana, R., (2009). Uji Kesamaan Vektor Parameter Model Linier Multivariat : Studi Kasus Faktor-Faktor Yang Mempengaruhi IPM tahun 2007. Tesis Jurusan Statistika FMIPA ITS. Surabaya.

[13] Faidah. D.Y., (2010). Pemodelan Regresi Probit Ordinal Pada Indeks Pembangunan Manusia Di Provinsi Sumatera Utara, Jawa Barat, Jawa Tengah, dan Jawa Timur. Skripsi Jurusan Statistika FMIPA ITS. Surabaya.

[14] Faidah. D.Y., (2012). Model Tobit Spasial Pada Faktor-Faktor Yang Mempengaruhi Tingkat Pengangguran Terbuka (TPT) Perempuan. Tesis Jurusan Statistika FMIPA ITS. Surabaya

[15] Greene, W.H. (2008). Econometrics Analysis. Sixth Edition, Prentice Hall, Englewood Cliffs, New Jersey.

[16] Greenberg, B.G. (1980)."Chester I. Bliss, 1899-1979." International Statistical Review/ Revue Internationale de Statistique, volume 8 halaman 135-136.

[17] Gujarati, D. N. (2003). Basic Econometric. Fourth Edition. McGraw-Hill, New York.

[18] Hocking, R., (1996). Methods and Aplication of Linear Models. John Wiley \& Sons, New York.

[19] Kutner, M.H., Nachtsheim, C.J., dan Nether, J. (2008). Applied Linear Regression Models. McGraw-Hill Companies. New York.
[20] Lee, J., \& Wong, D.W.S., (2001). Statistical Analysis With Arcview GIS. John Wiley and Sons, New York.

[21] LeSage, .P. (1999). The Theory and Practice of Spatial Econometrics. www.econ.utoledo.edu. Diunduh tanggal 10 September 2012.

[22] LeSage, J.P., dan Smith, T.E. (2002). A Bayesian Probit Model With Spatial Dependencies. Philadephia.

[23] Mustari, A.S., (2012). Analisis Regresi Tobit Spasial Studi Kasus Penggunaan Internet di Pulau Jawa. Tesis Jurusan Statistika FMIPA ITS. Surabaya.

[24] Naja, A.H., (2006). Pendidikan Berkualitas dan pembangunan SDM : Solusi Utama Masalah Pengangguran dan Kemiskinan di Indonesia. Jurnal Bisnis dan Ekonomi Politik, (7(1), 67-79.

[25] O’Donnell, C. dan Connor, D.H. (1996). Predicting the Saverity of Motor Vehicle Accident Injuries Using Models of Ordered Multiple Choice., Accident Analysis an Prevention, volume 28 No 6 halaman 739753.

[26] Salam, R., (2008). Pengujian Kesamaan Vektor Parameter Pada Beberapa Model Regrsi Logistik Ordinal (Faktor-Faktor yang mempngaruhi indeks pembangunan Manusi di Provinsi Jawa Timur, Nusa Tenggara Timur, Papua pada tahun 2006). Tesis Jurusan Statistika FMIPA ITS. Surabaya.

[27] Setiawan, D., (2004). Banyak Faktor Pengaruhi Belum Tercapainya IPM. [http://www.kompas.com] (tanggal akses : 26 September 2012, jam 20.00 WIB).

[28] Suanita., (2006). Ketimpangan Pengeluaran Perkapita Antar Daerah di Provinsi Sumatera Selatan. Kajian Ekonomi , 5(1), 71-92.

[29] Urip, S., (2007). Perkembangan Jumlah Penduduk Miskin dan Faktor Penyebabnya. [http://www.google.com\} (tanggal akses 20 September 2012, jam 20.00 WIB).

[30] Wachid., (2000). Faktor-Faktor Yang Mempengaruhi Kualitas Hidup Manusia. Kajian Ekonomi, 5(1), 108-133.

[31] Walpole, R. E., (1995). Pengantar Statistika. PT. Gramedia Pustaka Utama, Jakarta. 
[32] Wang, H., Iglesias, E.M, dan Wooldridge, J.M. (2009). Partial Maximum Likelihood Estimation of A Spatial Probit Model. Michigan State University.

[33] Widarjono, A., (2007). Ekonometrika Teori dan Aplikasi untuk Ekonomi dan Bisnis. Ekonisia, Yogyakarta.
[34] Winkelmann, R. dan Boes, S. (2006). Analysis of Microdata. Springer-Verlag Berlin Heidelberg, German.

[35] Yurviany., (2007). Analisis Regresi Logistik Pada Data Indeks Pembangunan Manusia Di Propinsi Jawa Timur. Skripsi Jurusan Statistika FMIPA ITS. Surabaya. 